\title{
Mengukur Potensi Perpindahan Nasabah Perbankan Kategori Milenial pada Layanan Pembiayaan Fintech Lending
}

\author{
Muhammad Anif Afandi ${ }^{a, *}$ \\ ${ }^{a}$ Fakultas Ekonomi dan Bisnis, Universitas Muhammadiyah Metro
}

\begin{abstract}
The purpose of this study is to measure the potential of millennial banking customers to switch to the financing services of FinTech lending and its influencing factors in the area of DKI Jakarta. Multinomial Logistic Regression (MLR) method is applied as the dependent variable has more than two categories. The results showed that the likelihood for banking customers were reluctant, likely and willing to switch to the financing services of FinTech lending amounts to 7.73 percent, 97.19 percent and 2.81 percent, respectively. The most affecting factors of banking customers to switch to the FinTech lending are pricing problem and ease of use. Meanwhile, inertia serves as an inhibitory factor of customer switching. The results of this study provide useful information for the managerial level in the banking industries, FinTech lending as well as the regulators for determining the appropriate strategies and policies to cope with customer switching.
\end{abstract}

Keywords: customer switching; banking; FinTech lending; MLR; DKI Jakarta

\begin{abstract}
Abstrak
Penelitian ini bertujuan untuk mengukur potensi perpindahan nasabah perbankan kategori milenial pada layanan pembiayaan FinTech lending di DKI Jakarta dan faktor-faktor yang memengaruhinya. Multinomial Logistic Regression (MLR) digunakan sebagai teknik analisis data karena variabel terikat terdiri dari lebih dari dua kategori. Hasil penelitian menunjukkan bahwa peluang nasabah perbankan yang tidak bersedia, mungkin pindah dan bersedia untuk pindah pada layanan pembiayaan FinTech lending masing-masing sebesar 7,73 persen, 97,19, persen dan 2,81 persen. Faktor yang paling memengaruhi terjadinya perpindahan nasabah tersebut adalah pricing problem dan ease of use. Selain itu, inertia menjadi faktor penghambat terjadinya perpindahan nasabah. Hasil penelitian ini memberikan informasi yang bermanfaat bagi pihak manajerial, baik pada industri perbankan, FinTech lending, maupun regulator untuk dapat menentukan strategi dan kebijakan yang tepat di tengah potensi terjadinya perpindahan nasabah.
\end{abstract}

Kata Kunci: customer switching; perbankan; FinTech lending; MLR; DKI Jakarta Klasifikasi JEL: G4; M3

\footnotetext{
${ }^{*}$ Alamat Penulis Korespondensi: Jl. Ki Hajar Dewantara No. 116 Iringmulyo, Metro Timur, Kota Metro, Lampung. E-mail: afandianif@gmail.com.
} 


\section{Pendahuluan}

Perkembangan teknologi merupakan salah satu pencapaian terbesar dari Revolusi Industri 4.0 yang memunculkan fenomena yang disebut disruption. Menurut Kasali (2018), disruption diartikan sebagai sebuah perubahan yang terjadi akibat hadirnya masa depan ke masa kini melalui kehadiran sesuatu yang baru dan mengubah sesuatu yang telah berjalan secara normal. Salah satu kebaruan yang dimaksud adalah munculnya model bisnis baru dengan lahirnya perusahaan new entrants yang mendisrupsi model bisnis perusahaan incumbents-nya dari seluruh aspek proses bisnis yaitu produksi, konsumsi, transportasi, dan distribusi (Schwab, 2017).

Salah satu industri yang diprediksi akan terdisrupsi dengan kehadiran model bisnis baru perusahaan new entrants adalah industri perbankan dengan hadirnya industri serupa yang memanfaatkan teknologi sebagai keunggulan kompetitifnya atau disebut sebagai Financial Technology (FinTech). Menurut Jun dan Yeo (2018), disrupsi FinTech lending dapat berdampak pada instabilitas sistem perbankan apabila tidak terdapat pengaturan/perbedaan segmentasi pasar antara FinTech lending dan perbankan, yaitu sama-sama bersaing pada segmen mid/low-credit score. Sedangkan, jika terdapat pengaturan/perbedaan segmentasi pasar antara FinTech lending yang berfokus pada segmen mid/low-credit score dan perbankan yang berfokus pada segmen high-credit score, maka instabilitas sistem perbankan diharapkan dapat dicegah.

Perpindahan nasabah (customer switching) merupakan salah satu kategori yang diprediksi akan terdisrupsi dengan adanya FinTech lending (PricewaterhouseCoopers, 2016). Namun, penelitian mengenai pengukuran potensi perpindahan nasabah perbankan pada layanan pembiayaan FinTech lending disertai dengan faktor-faktor yang memengaruhinya cenderung masih terbatas. Maier (2016) mengkaji mengenai perpindahan nasabah perbankan pada layanan pembiayaan crowdlending dengan menggunakan objek penelitian, yaitu UMKM, namun hanya terbatas pada faktor-faktor yang memengaruhi perpindahan tersebut yang dianalisis menggunakan empat dimensi, yaitu technical dimension, functional dimension, image, dan innovativeness.

Penelitian lain yang membahas mengenai fenomena perpindahan nasabah perbankan pada layanan pembiayaan FinTech lending cenderung masih tersegmentasi pada masing-masing sektor, misalnya perpindahan nasabah dari bank satu ke bank lainnya atau dari satu jenis FinTech ke jenis FinTech lainnya, seperti penelitian yang dilakukan oleh Al-hawari (2014), Vyas dan Raitani (2014), Piha dan Avlonitis (2015), Bakar et al. (2017), Farah (2017a,b), Koutsothanassi et al. (2017), Lee et al. (2019), dan Wang et al. (2019).

Selain itu, pada penelitian terdahulu juga masih sangat jarang ditemukan literatur yang fokus untuk membahas mengenai fenomena perpindahan nasabah perbankan pada layanan pembiayaan FinTech lending dengan menggunakan kategori nasabah milenial. Padahal, berdasarkan laporan TransferWise (2016), peningkatan jumlah milenial merupakan salah satu penyebab diterimanya industri 
FinTech sebagai pemain baru dalam pasar industri keuangan selain penurunan kepercayaan nasabah perbankan akibat adanya krisis keuangan global tahun 2008, ekspektasi yang lebih baik terhadap industri FinTech, peningkatan penggunaan mobile internet, dan regulasi yang mendukung keberadaan FinTech.

Oleh karena itu, dari adanya gap bahwa penelitian terdahulu yang membahas mengenai perpindahan nasabah perbankan pada layanan pembiayaan FinTech lending masih sangat terbatas dan tersegmentasi pada masing-masing sektor, maka penelitian ini menganalisis secara komprehensif mengenai fenomena perpindahan nasabah perbankan pada layanan pembiayaan FinTech lending dengan objek nasabah kategori milenial yang menjadi kelompok generasi terbesar saat ini. Hasil penelitian ini bermanfaat bagi pihak manajerial, baik pada industri perbankan, FinTech lending, maupun regulator untuk dapat menentukan strategi atau kebijakan terbaik untuk menghadapi potensi terjadinya perpindahan nasabah.

\section{Metode Penelitian}

Penelitian ini menggunakan desain penelitian berupa penelitian kuantitatif yang bertujuan untuk mengukur potensi perpindahan nasabah perbankan kategori milenial pada layanan pembiayaan FinTech lending di wilayah DKI Jakarta. Sampel penelitian yang digunakan diambil menggunakan teknik non-probability sampling jenis purposive sampling dengan kriteria nasabah yang pernah melakukan kredit/pembiayaan di bank konvensional mencakup Bank Umum Konvensional atau bank syariah mencakup Bank Umum Syariah dalam kurun waktu 5 tahun terakhir, berusia 18-39 tahun sebagai representasi usia generasi milenial, mengetahui dan belum pernah menggunakan layanan pembiayaan FinTech lending, serta berdomisili di wilayah DKI Jakarta.

Variabel penelitian yang digunakan dalam penelitian ini mengadopsi dari teori Push-Pull-Mooring (PPM) yang dikembangkan oleh Bansal et al. (2005). Teori PPM terdiri dari tiga efek, yaitu push effects yang merupakan faktor negatif dari layanan yang digunakan saat ini sehingga mendorong pelanggan untuk berpindah pada layanan lainnya. Efek kedua, yaitu pull effects merupakan faktor positif dari layanan yang dituju sehingga menarik pelanggan untuk berpindah layanan dan efek ketiga, yaitu mooring effects merupakan faktor yang menghambat terjadinya perpindahan pelanggan (Bansal et al., 2005). Namun, dalam penelitian ini dilakukan modifikasi variabel penelitian berdasarkan teori PPM (lihat Tabel 1).

Penelitian ini dilakukan dengan menggunakan teknik pengumpulan data berupa kuesioner dengan tipe jawaban yang diukur menggunakan skala Likert lima kategori, yaitu 1 = sangat tidak setuju hingga 5 = sangat setuju dalam rentang waktu 3 Mei-4 Juli 2019 secara online menggunakan media Google Form. Item/butir pertanyaan kuesioner yang digunakan dalam penelitian ini mengadopsi teori PPM seperti pada Tabel 1. Total 281 data primer berhasil dikumpulkan dari responden yang dijawab sesuai dengan pengalaman yang mereka alami dan selanjutnya dilakukan analisis menggunakan prosedur statistik menggunakan 


\section{Tabel 1: Variabel Penelitian}

\begin{tabular}{|c|c|c|c|}
\hline Nama Variabel & Jenis Variabel & Definisi Variabel & Sumber \\
\hline \multicolumn{4}{|l|}{ Push Effects } \\
\hline Pricing Problem & Independen & $\begin{array}{l}\text { Persepsi nasabah perbankan kategori mi- } \\
\text { lenial terhadap biaya yang dibebankan } \\
\text { pada layanan kredit/pembiayaan per- } \\
\text { bankan yang dapat mendorong nasabah } \\
\text { untuk berpindah pada layanan pembia- } \\
\text { yaan FinTech lending }\end{array}$ & $\begin{array}{l}\text { Vyas dan Raita- } \\
\text { ni (2014) }\end{array}$ \\
\hline Processing & Independen & Persepsi nasabah perbankan kategori mi- & Maier (2016) \\
\hline Problem & & $\begin{array}{l}\text { lenial terhadap prosedur/persyaratan } \\
\text { dalam hal pengajuan kredit/pembiayaan } \\
\text { di perbankan yang dapat mendorong } \\
\text { nasabah untuk berpindah pada layanan } \\
\text { pembiayaan FinTech lending }\end{array}$ & \\
\hline Service Quality & Independen & $\begin{array}{l}\text { Persepsi nasabah perbankan kategori } \\
\text { milenial terhadap kualitas layanan per- } \\
\text { bankan selama proses pengajuan kre- } \\
\text { dit/pembiayaan yang dapat mendorong } \\
\text { nasabah untuk berpindah pada layanan } \\
\text { pembiayaan FinTech lending }\end{array}$ & $\begin{array}{l}\text { Vyas dan Raita- } \\
\text { ni (2014) }\end{array}$ \\
\hline \multicolumn{4}{|l|}{ Pull Effects } \\
\hline Easy Process & Independen & $\begin{array}{l}\text { Persepsi nasabah perbankan kategori mi- } \\
\text { lenial terhadap kemudahan proses dalam } \\
\text { hal pengajuan kredit/pembiayaan mela- } \\
\text { lui FinTech lending yang dapat menarik } \\
\text { nasabah perbankan untuk berpindah pa- } \\
\text { da layanan pembiayaan FinTech lending }\end{array}$ & Maier (2016) \\
\hline Ease of Use & Independen & $\begin{array}{l}\text { Persepsi nasabah perbankan kategori mi- } \\
\text { lenial terhadap kemudahan dalam hal } \\
\text { pengajuan kredit/pembiayaan melalui } \\
\text { FinTech lending karena didukung dengan } \\
\text { pemanfaatan teknologi berbasis internet } \\
\text { yang dapat menarik nasabah perbankan } \\
\text { untuk berpindah pada layanan pembia- } \\
\text { yaan FinTech lending }\end{array}$ & $\begin{array}{l}\text { Ye dan Potter } \\
(2011)\end{array}$ \\
\hline Pricing Benefit & Independen & $\begin{array}{l}\text { Persepsi nasabah perbankan kategori mi- } \\
\text { lenial terhadap keuntungan yang dipero- } \\
\text { leh akibat biaya yang dibebankan pada } \\
\text { layanan kredit/pembiayaan FinTech len- } \\
\text { ding yang lebih murah dibandingkan de- } \\
\text { ngan kredit/pembiayaan di bank yang } \\
\text { dapat menarik nasabah perbankan un- } \\
\text { tuk berpindah pada layanan pembiayaan } \\
\text { FinTech lending }\end{array}$ & $\begin{array}{l}\text { Vyas dan Raita- } \\
\text { ni (2014) }\end{array}$ \\
\hline Inertia & Independen & $\begin{array}{l}\text { Perilaku pengguna (nasabah perbankan } \\
\text { kategori milenial) yang tetap bertahan } \\
\text { pada layanan kredit/pembiayaan per- } \\
\text { bankan meskipun terdapat layanan kre- } \\
\text { dit/pembiayaan FinTech lending }\end{array}$ & Li (2018) \\
\hline
\end{tabular}


Tabel 1 (sambungan)

\begin{tabular}{|c|c|c|c|}
\hline Nama Variabel & Jenis Variabel & Definisi Variabel & Sumber \\
\hline \multicolumn{4}{|l|}{ Mooring Effects } \\
\hline Inertia & Independen & $\begin{array}{l}\text { Perilaku pengguna (nasabah perbankan } \\
\text { kategori milenial) yang tetap bertahan } \\
\text { pada layanan kredit/pembiayaan per- } \\
\text { bankan meskipun terdapat layanan kre- } \\
\text { dit/pembiayaan FinTech lending }\end{array}$ & Li (2018) \\
\hline Security & Independen & $\begin{array}{l}\text { Persepsi nasabah perbankan kategori mi- } \\
\text { lenial terhadap aspek keamanan pada } \\
\text { layanan kredit/pembiayaan FinTech len- } \\
\text { ding yang dapat menghambat terjadinya } \\
\text { perpindahan nasabah }\end{array}$ & $\begin{array}{l}\text { Ye dan Potter } \\
(2011)\end{array}$ \\
\hline Service Products & Independen & $\begin{array}{l}\text { Persepsi nasabah perbankan kategori mi- } \\
\text { lenial terhadap produk/layanan yang di- } \\
\text { tawarkan oleh FinTech lending untuk me- } \\
\text { menuhi kebutuhan penggunanya yang } \\
\text { dapat menghambat terjadinya perpin- } \\
\text { dahan nasabah }\end{array}$ & $\begin{array}{l}\text { Vyas dan Raita- } \\
\text { ni (2014) }\end{array}$ \\
\hline Reputation & Independen & $\begin{array}{l}\text { Persepsi/gambaran yang melekat dari } \\
\text { nasabah perbankan kategori milenial ter- } \\
\text { hadap layanan kredit/pembiayaan pada } \\
\text { FinTech lending yang dapat menghambat } \\
\text { terjadinya perpindahan nasabah }\end{array}$ & $\begin{array}{l}\text { Vyas dan Raita- } \\
\text { ni (2014) }\end{array}$ \\
\hline \multicolumn{4}{|c|}{ Switching Intentions } \\
\hline $\begin{array}{l}\text { Switching Inten- } \\
\text { tions }\end{array}$ & Dependen & $\begin{array}{l}\text { Intensi nasabah perbankan kategori mi- } \\
\text { lenial untuk beralih ke layanan kre- } \\
\text { dit/pembiayaan FinTech lending }\end{array}$ & $\begin{array}{l}\text { 1: Bersedia un- } \\
\text { tuk pindah la- } \\
\text { yanan } \\
\text { 2: Mungkin un- } \\
\text { tuk pindah la- } \\
\text { yanan } \\
\text { 3: Tidak berse- } \\
\text { dia untuk pin- } \\
\text { dah layanan }\end{array}$ \\
\hline
\end{tabular}

Sumber: Diolah dari berbagai sumber (2019) 
model Multinomial Logistic Regression (MLR).

Sebelum dilakukan analisis data menggunakan model MLR, maka terlebih dahulu dilakukan uji validitas dan reliabilitas untuk menguji ketepatan daftar pertanyaan sebagai alat ukur variabel penelitian dan konsistensi responden dalam menjawab pertanyaan penelitian. Indikator yang digunakan untuk uji validitas adalah kaiser-meyer-olkin, anti-image matrices, communalities, dan component matrix (Malhotra, 2016). Sedangkan, untuk menguji reliabilitas indikator yang digunakan adalah nilai Cronbach's alpha (Edison, 2015).

Setelah seluruh butir pertanyaan penelitian memenuhi asumsi validitas dan reliabilitas, maka pengujian selanjutnya yaitu model MLR dapat dilakukan. Menurut Hsu dan Chang (2007) dan El-Habil (2012), model MLR merupakan teknik yang paling penting dan efektif digunakan untuk menganalisis data kategori yang berjumlah lebih dari dua. Data kategori yang dimaksud dalam penelitian ini seperti yang ditunjukkan dalam Tabel 1 adalah intensi untuk berpindah nasabah perbankan kategori milenial pada layanan pembiayaanFintech lending yang terdiri dari tiga kategori, yaitu bersedia, mungkin akan pindah, dan tidak bersedia untuk pindah.

Yang dimaksud dengan kategori bersedia adalah nasabah perbankan kategori milenial telah memutuskan akan berpindah pada layanan kredit/pembiayaan FinTech lending. Yang dimaksud dengan kategori mungkin akan pindah adalah nasabah perbankan kategori milenial masih mempertimbangkan apakah akan berpindah pada layanan kredit/pembiayaan FinTech lending atau tidak. Sedangkan, yang dimaksud dengan kategori tidak bersedia untuk pindah adalah nasabah perbankan kategori milenial telah memutuskan untuk tetap menggunakan layanan kredit/pembiayaan perbankan atau tidak berminat untuk pindah menggunakan layanan kredit/pembiayaan FinTech lending.

Selain itu, model MLR tidak memerlukan uji asumsi klasik seperti Ordinary Least Square (OLS), namun pengujian multikolinearitas tetap diperlukan (El-Habil, 2012). Model MLR yang digunakan dalam penelitian ini adalah sebagai berikut:

$$
\begin{aligned}
& \operatorname{Ln}\left(\frac{P_{1}}{P_{0}}\right)=\beta_{0 i}+\beta_{1 i} X_{1 i}+\beta_{2 i} X_{2 i}+\cdots \beta_{X i} X_{x i} \\
& \operatorname{Ln}\left(\frac{P_{2}}{P_{0}}\right)=\beta_{0 j}+\beta_{1 j} X_{1 i}+\beta_{2 j} X_{2 i}+\cdots \beta_{X j} X_{x i}
\end{aligned}
$$

Dimana $P_{1}$ merupakan variabel dependen kategori $1, P_{2}$ merupakan variabel dependen kategori 2, dan $P_{3}$ sebagai referensi. $\beta_{0 i}$ merupakan intercept untuk model 1 dan $\beta_{0 j}$ merupakan intercept untuk model 2. $\beta_{1 i} X_{1 i}, \beta_{2 i} X_{2 i}, \beta_{X i} X_{x i}$ merupakan slope untuk model 1 dan $\beta_{1 j} X_{1 i}, \beta_{2 j} X_{2 i}, \beta_{X j} X_{x i}$ merupakan slope untuk model 2. 


\section{Hasil dan Pembahasan}

\subsection{Profil Responden}

Sebelum dilakukan analisis menggunakan model MLR, maka terlebih dahulu perlu dijelaskan mengenai profil responden yang digunakan dalam penelitian ini (lihat Tabel 2).

Tabel 2: Profil Responden $(\mathrm{N}=\mathbf{2 8 1})$

\begin{tabular}{llrr}
\hline Variabel & Kategori & Jumlah & Persentase \\
\hline Gender & Laki-laki & 167 & 59.4 \\
Usia & Perempuan & 114 & 40.6 \\
& $<20$ & 21 & 7.5 \\
\multirow{5}{*}{ Pendidikan Terakhir } & $20-29$ & 161 & 57.3 \\
& $30-39$ & 99 & 35.2 \\
& SMA sederajat & 132 & 47 \\
& Diploma & 24 & 8.6 \\
Pekerjaan & Sarjana & 117 & 41.6 \\
& Magister atau Doktoral & 8 & 2.8 \\
& Wirausaha & 20 & 7.1 \\
Agama & Karyawan Swasta atau Sektor Publik & 203 & 71.7 \\
& Ibu Rumah Tangga & 22 & 7.8 \\
& Lainnya & 36 & 12.8 \\
& Islam & 208 & 74 \\
& Katolik & 19 & 6.8 \\
& Protestan & 41 & 14.6 \\
& Hindu & 1 & 0.4 \\
& Budha & 11 & 3.9 \\
Pendapatan per bulan & Konghucu & 1 & 0.4 \\
& LRp1,5 Juta & 32 & 11.4 \\
& Rp1,6-Rp4,5 Juta & 140 & 49.8 \\
& Rp4,6-Rp 10 Juta & 90 & 32 \\
Bank yang digunakan & Bank Konvensional & 19 & 6.8 \\
& Bank Syariah & 179 & 63.7 \\
\hline Sumber: Data diolah $(2019)$ & 102 & 36.3 \\
\hline & & &
\end{tabular}

Sumber: Data diolah (2019)

Tabel 2 menginformasikan bahwa responden penelitian dengan jenis kelamin laki-laki lebih banyak, yaitu 167 orang dibanding yang berjenis kelamin perempuan dengan jumlah 114 orang. Usia mayoritas milenial dalam penelitian ini, yaitu pada kisaran 20-29 tahun sebanyak 161 orang. Selain itu, pendidikan terakhir yang ditempuh milenial mayoritas adalah sarjana sebanyak 117 orang dan bekerja sebagai staf, baik pada sektor swasta maupun sektor publik. 208 responden mengaku beragama Islam dan mayoritas berpendapatan pada kisaran Rp1,6-Rp4,5 juta per bulan. Selanjutnya, responden memberikan informasi bahwa 179 orang pernah melakukan kredit pada bank konvensional, sementara 102 orang pernah melakukan pembiayaan di bank syariah dalam 5 tahun terakhir. 


\subsection{Uji Validitas dan Reliabilitas}

Setelah dijelaskan mengenai profil responden, maka selanjutnya dilakukan uji validitas dan reliabilitas terhadap butir pertanyaan kuesioner dengan pengujian Kaiser-Meyer-Olkin, anti-image matrices, communalities, component matrix, dan Cronbach's alpha dengan output yang ditunjukkan pada Tabel 3.

Tabel 3: Analisis Faktor

\begin{tabular}{|c|c|c|c|c|c|}
\hline Variabel & $\begin{array}{l}\text { Indikator } \\
\text { Variabel }\end{array}$ & $\mathrm{KMO}$ & $\begin{array}{c}\text { Anti-Image } \\
\text { Matrices }\end{array}$ & Communalities & $\begin{array}{c}\text { Component } \\
\text { Matrix }\end{array}$ \\
\hline \multirow{2}{*}{ Pricing Problem } & Item1 & 0,500 & 0,500 & 0,896 & 0,946 \\
\hline & Item2 & & 0,500 & 0,896 & 0,946 \\
\hline \multirow[t]{2}{*}{ Processing Problem } & Item3 & 0,500 & 0,500 & 0,816 & 0,903 \\
\hline & Item 4 & & 0,500 & 0,816 & 0,903 \\
\hline \multirow[t]{5}{*}{ Service Quality } & Item 5 & 0,815 & 0,781 & 0,540 & 0,735 \\
\hline & Item6 & & 0,762 & 0,788 & 0,887 \\
\hline & Item7 & & 0,867 & 0,708 & 0,842 \\
\hline & Item8 & & 0,837 & 0,740 & 0,860 \\
\hline & Item9 & & 0,847 & 0,530 & 0,728 \\
\hline \multirow[t]{3}{*}{ Easy Process } & Item 10 & 0,590 & 0,575 & 0,535 & 0,731 \\
\hline & Item11 & & 0,580 & 0,515 & 0,717 \\
\hline & Item 12 & & 0,629 & 0,401 & 0,633 \\
\hline \multirow[t]{2}{*}{ Ease of Use } & Item 13 & 0,500 & 0,500 & 0,733 & 0,856 \\
\hline & Item14 & & 0,500 & 0,733 & 0,856 \\
\hline \multirow[t]{2}{*}{ Pricing Benefit } & Item15 & 0,500 & 0,500 & 0,813 & 0,902 \\
\hline & Item16 & & 0,500 & 0,813 & 0,902 \\
\hline \multirow[t]{2}{*}{ Inertia } & Item17 & 0,500 & 0,500 & 0,709 & 0,842 \\
\hline & Item18 & & 0,500 & 0,709 & 0,842 \\
\hline \multirow[t]{2}{*}{ Security } & Item19 & 0,500 & 0,500 & 0,824 & 0,908 \\
\hline & Item 20 & & 0,500 & 0,824 & 0,908 \\
\hline \multirow[t]{2}{*}{ Service Products } & Item21 & 0,500 & 0,500 & 0,800 & 0,895 \\
\hline & Item 22 & & 0,500 & 0,800 & 0,895 \\
\hline \multirow[t]{2}{*}{ Reputation } & Item 23 & 0,500 & 0,500 & 0,842 & 0,918 \\
\hline & Item 24 & & 0,500 & 0,842 & 0,918 \\
\hline
\end{tabular}

Sumber: Data diolah (2019)

Tabel 3 menginformasikan mengenai output uji validitas. Dari output tersebut diketahui bahwa seluruh butir pertanyaan penelitian dalam kuesioner telah memenuhi asumsi uji validitas yang dapat diketahui dari nilai Kaiser-Meyer-Olkin $>0,5$ artinya seluruh data yang digunakan dapat diproses lebih lanjut. Selain itu, seluruh butir penelitian terbebas dari anti-image matrices yang diketahui dari seluruh nilai Measures of Sampling Adequacy (MSA) yang bernilai >0,5. Setiap butir pertanyaan juga diketahui dapat menjelaskan dan berkorelasi dengan variabelnya dengan nilai yang cukup tinggi, yaitu lebih dari 0,5 yang ditunjukkan dari pengujian communalities dan component matrix.

Setelah diketahui bahwa seluruh butir pertanyaan penelitian telah memenuhi uji validitas atau dikatakan valid, maka pengujian selanjutnya adalah uji reliabilitas yang bertujuan untuk mengetahui konsistensi responden dalam menjawab pertanyaan penelitian dalam kuesioner. Pertanyaan penelitian memenuhi asumsi reliabilitas jika nilai Cronbach's alpha >0,6 (Edison, 2015). Dalam Tabel 3 diketa- 
Tabel 4: Uji Reliabilitas

\begin{tabular}{ccc}
\hline Cronbach's Alpha & Cronbach's Alpha Based on Standardized Items & Nof Items \\
\hline 0,781 & 0,766 & 24 \\
\hline
\end{tabular}

Sumber: Data diolah (2019)

hui bahwa nilai Cronbach's alpha sebesar 0,781>0,6, maka seluruh pertanyaan penelitian ini dikatakan reliabel.

\subsection{Multinomial Logistic Regression}

(MLR) Setelah data penelitian memenuhi persyaratan uji validitas dan reliabilitas, selanjutnya dapat dilakukan pengujian Multinomial Logistic Regression (MLR) yang outputnya dapat ditunjukkan dalam Tabel 4.

Tabel 5: Output Model MLR

\begin{tabular}{|c|c|c|c|c|c|c|c|}
\hline \multicolumn{2}{|c|}{ Switching_Intentions ${ }^{a}$} & B & Std. Error & Wald & $\mathrm{df}$ & Sig. & $\operatorname{Exp}(B)$ \\
\hline \multirow[t]{11}{*}{1} & Intercept & $-1,014$ & 1,759 & 0,333 & 1 & 0,564 & \\
\hline & Pricing Problem & 0,320 & 0,134 & 5,735 & 1 & 0,017 & 0,726 \\
\hline & Processing Problem & 0,151 & 0,223 & 0,459 & 1 & 0,498 & 1,163 \\
\hline & Service Quality & 0,188 & 0,104 & 3,244 & 1 & 0,072 & 1,207 \\
\hline & Easy Process & 0,059 & 0,164 & 0,129 & 1 & 0,719 & 1,061 \\
\hline & Ease of Use & 0,520 & 0,230 & 5,098 & 1 & 0,024 & 1,681 \\
\hline & Pricing Benefit & 0,194 & 0,158 & 1,501 & 1 & 0,220 & 1,214 \\
\hline & Inertia & $-0,467$ & 0,182 & 6,601 & 1 & 0,010 & 0,627 \\
\hline & Security & $-0,258$ & 0,198 & 1,691 & 1 & 0,193 & 0,773 \\
\hline & Service Products & $-0,086$ & 0,185 & 0,214 & 1 & 0,644 & 0,918 \\
\hline & Reputation & $-0,035$ & 0,197 & 0,031 & 1 & 0,860 & 0,966 \\
\hline \multirow[t]{11}{*}{2} & Intercept & 2,531 & 1,400 & 3,267 & 1 & 0,071 & \\
\hline & Pricing Problem & 0,199 & 0,108 & 3,406 & 1 & 0,065 & 0,820 \\
\hline & Processing Problem & 0,265 & 0,180 & 2,172 & 1 & 0,141 & 1,303 \\
\hline & Service Quality & 0,085 & 0,083 & 1,059 & 1 & 0,303 & 1,089 \\
\hline & Easy Process & 0,082 & 0,129 & 0,400 & 1 & 0,527 & 1,085 \\
\hline & Ease of Use & 0,045 & 0,171 & 0,069 & 1 & 0,793 & 1,046 \\
\hline & Pricing Benefit & 0,194 & 0,129 & 2,283 & 1 & 0,131 & 1,214 \\
\hline & Inertia & $-0,446$ & 0,146 & 9,332 & 1 & 0,002 & 0,640 \\
\hline & Security & $-0,054$ & 0,160 & 0,114 & 1 & 0,736 & 0,947 \\
\hline & Service Products & $-0,085$ & 0,153 & 0,310 & 1 & 0,578 & 0,919 \\
\hline & Reputation & $-0,102$ & 0,161 & 0,399 & 1 & 0,528 & 0,903 \\
\hline
\end{tabular}

Sebelum dilakukan analisis terhadap output MLR, maka terlebih dahulu dapat 
dituliskan model MLR sesuai dengan Tabel 4 sebagai berikut:

$$
\begin{aligned}
\operatorname{Ln}\left(\frac{P_{1}}{P_{0}}\right)= & -1,014+0,320 \text { Pricing problem }+0,151 \text { Processing problem } \\
& +0,188 \text { Service Quality }+0,059 \text { Easy process } \\
& +0,520 \text { Ease of Use }+0,194 \text { Pricing benefit }-0,467 \text { Inertia } \\
& -0,258 \text { Security }-0,086 \text { Service products }-0,035 \text { Reputation } \\
\operatorname{Ln}\left(\frac{P_{2}}{P_{0}}\right)= & 2,531+0,199 \text { Pricing problem }+0,265 \text { Processing problem } \\
& +0.085 \text { Service Quality }+0,082 \text { Easy process } \\
& +0,045 \text { Ease of Use }+0,194 \text { Pricing benefit }-0,446 \text { Inertia } \\
& -0,054 \text { Security }-0,085 \text { Service products }-0,102 \text { Reputation }
\end{aligned}
$$

\subsection{Pembahasan}

Dari perspektif efek push pada MLR model 1 diketahui bahwa hanya pricing problem yang berpengaruh positif dan signifikan terhadap switching intentions dengan nilai eksponensial sebesar 0,726. Artinya, kecenderungan nasabah perbankan kategori milenial untuk berpindah pada layanan pembiayaan FinTech lending yang disebabkan oleh faktor pricing problem pada layanan kredit/pembiayaan di perbankan sebesar 72,6 persen. Dengan kata lain, biaya administrasi maupun bunga/bagi hasil yang dibebankan kepada nasabah oleh perbankan dinilai masih cenderung mahal.

Kontribusi faktor pricing terhadap switching intentions mengonfirmasi penelitian yang dilakukan oleh Gerrard dan Cunningham (2004) dan Vyas dan Raitani (2014). Menurut Gerrard dan Cunningham (2004), pricing merupakan faktor yang lebih tinggi pengaruhnya terhadap perpindahan nasabah daripada kualitas layanan (service quality). Selain itu, pricing merupakan salah satu faktor yang sangat menentukan competitiveness perbankan (Gerrard \& Cunningham, 2004). Oleh karena itu, menurut Vyas dan Raitani (2014), pihak perbankan perlu melakukan evaluasi terhadap pricing yang dibebankan pada nasabah, baik pada biaya administrasi maupun bunga/bagi hasil dari aktivitas lending.

Sedangkan, dalam perspektif efek pull pada MLR model 1 diketahui bahwa hanya faktor ease of use yang berpengaruh positif dan signifikan terhadap switching intentions dengan nilai eksponensial sebesar 1,681. Artinya, kecenderungan nasabah perbankan kategori milenial untuk berpindah pada layanan pembiayaan FinTech lending yang didorong oleh faktor ease of use sebesar 1,681 persen. Pemanfaatan teknologi sebagai keunggulan kompetitif FinTech lending dinilai lebih fleksibel/menguntungkan sehingga mendorong calon nasabah untuk berpindah dari layanan perbankan yang digunakan saat ini (Ye \& Potter, 2011).

Sementara itu, dari perspektif efek mooring pada MLR model 1 diketahui bahwa hanya inertia yang menyumbang pengaruh negatif dan signifikan terhadap switching intentions dengan nilai eksponensial sebesar 0,627. Artinya, 
kecenderungan nasabah perbankan kategori milenial untuk tidak berpindah pada layanan pembiayaan FinTech lending yang dihambat oleh faktor inertia sebesar 62,7 persen. Dengan kata lain, nasabah perbankan kategori milenial memiliki tingkat loyalitas yang cukup tinggi untuk terus menggunakan layanan kredit/pembiayaan di perbankan.

Tingkat inertia yang cukup tinggi yang dimiliki oleh nasabah perbankan kategori milenial menyebabkan keinginan untuk mencari informasi baru yang berkaitan dengan layanan pembiayaan FinTech lending cenderung rendah sehingga menyebabkan keinginan untuk berpindah juga cenderung rendah ( $\mathrm{Li}$, 2018). Namun, meskipun tingkat inertia nasabah perbankan kategori milenial cukup tinggi tidak menutup kemungkinan bahwa nasabah perbankan kategori milenial akan berpindah pada layanan pembiayaan FinTech lending karena proses disruption sedang berlangsung dan diperkirakan akan stabil 5-10 tahun ke depan (Kasali, 2017).

Selanjutnya, pada MLR model 2 diketahui bahwa hanya faktor inertia yang memengaruhi switching intentions secara negatif dan signifikan dengan nilai eksponensial sebesar 0,640. Artinya, kecenderungan nasabah perbankan kategori milenial yang tidak bersedia untuk berpindah pada layanan pembiayaan FinTech lending sebesar 64 persen. Angka tersebut menjelaskan bahwa tingkat loyalitas nasabah perbankan kategori milenial cukup tinggi meskipun banyak kekurangan dari layanan perbankan yang diterima nasabah.

Tabel 6: Peluang Nasabah Perbankan untuk Berpindah pada Layanan Pembiayaan FinTech Lending

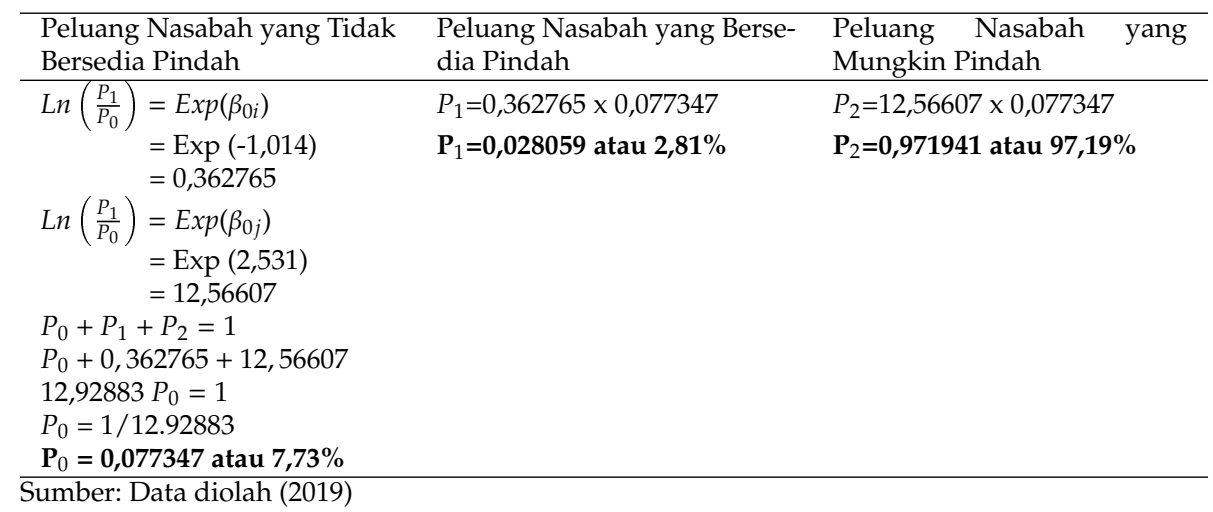

Setelah diketahui faktor-faktor PPM yang memberikan pengaruh terhadap perpindahan nasabah perbankan kategori milenial pada layanan pembiayaan FinTech lending, selanjutnya dapat dihitung peluang nasabah yang tidak bersedia pindah, mungkin pindah dan bersedia untuk pindah masing-masing sebesar 7,73 persen, 2,81 persen, dan 97,19 persen (Tabel 5).

Dari angka tersebut menunjukkan bahwa potensi terjadinya perpindahan nasabah perbankan kategori milenial pada layanan kredit/pembiayaan FinTech 
lending cukup rendah di wilayah DKI Jakarta, yaitu hanya sebesar 2,81 persen karena dihambat oleh efek mooring terutama tingkat inertia nasabah perbankan yang tinggi. Namun, angka tersebut bukan tidak mungkin akan terus meningkat karena jumlah calon nasabah yang sedang mempertimbangkan untuk beralih menggunakan layanan kredit/pembiayaan FinTech lending cukup tinggi di wilayah DKI Jakarta yaitu sebesar 97,19 persen.

Tabel 7: Output Model Fitting

\begin{tabular}{lccc|ccc}
\hline \multirow{2}{*}{ Model } & \multicolumn{3}{c}{ Model Fitting Criteria } & \multicolumn{3}{c}{ Likelihood Ratio Tests } \\
\cline { 2 - 7 } & AIC & BIC & -2 Log Likelihood & Chi-Square & df & Sig. \\
\hline Intercept Only & 508,580 & 515,857 & 504,580 & & & \\
Final & 486,872 & 566,915 & 442,872 & 61,709 & 20 & 0 \\
\hline Sumber: Data diolah (2019) & \multicolumn{6}{c}{}
\end{tabular}

Model MLR yang dihasilkan pada Tabel 4 telah memenuhi asumsi goodnessof-fit yang dapat diketahui dari nilai Chi-Square (Tabel 6) yang lebih kecil dari $\alpha=0,05$ sehingga $H_{0}$ ditolak atau dengan kata lain model MLR signifikan telah memenuhi asumsi goodness-of-fit (El-Habil, 2012). Selain itu, nilai AIC, BIC. dan -2 Log Likelihood yang cenderung berdekatan mengindikasikan bahwa model MLR dapat menjelaskan fenomena perpindahan nasabah perbankan kategori milenial pada layanan pembiayaan FinTech lending sesuai true expected values (El-Habil, 2012).

Model MLR tidak memerlukan uji asumsi klasik, namun tetap memerlukan uji multikolinearitas. Model MLR pada Tabel 4 telah terbebas dari multikolinearitas yang dapat diketahui dari nilai standard error yang kurang dari 2 sehingga dapat disimpulkan bahwa seluruh variabel independen yang digunakan tidak berkorelasi satu dengan lainnya (El-Habil, 2012). Selain itu, dalam model MLR terdapat pseudo-R-square yang berbeda dengan R2 pada OLS. Menurut El-Habil (2012), terdapat banyak keterbatasan pada $p s e u d o-R$-square untuk menjelaskan model MLR sehingga tidak dilakukan interpretasi terhadap nilai pseudo-R-square tersebut.

\section{Simpulan dan Saran}

Dari hasil dan pembahasan yang telah dilakukan dapat disimpulkan bahwa potensi terjadinya perpindahan nasabah perbankan kategori milenial pada layanan pembiayaan FinTech lending cukup rendah di wilayah DKI Jakarta, namun tidak menutup kemungkinan untuk terus meningkat seiring dengan meningkatnya persepsi positif calon nasabah terhadap layanan kredit/pembiayaan pada FinTech lending. Selain itu, faktor-faktor yang memengaruhi perpindahan nasabah tersebut dari perspektif push effects, yaitu pricing problem. Sedangkan, dari perspektif pull effects faktor yang memengaruhi perpindahan nasabah adalah ease of use. Sementara, dari perspektif mooring effects faktor yang menghambat terjadinya perpindahan nasabah adalah inertia. 
Dari hasil penelitian dapat diberikan rekomendasi, baik untuk industri perbankan, FinTech lending, maupun regulator, yaitu untuk industri perbankan dan FinTech lending perlu melakukan partnership model yang saling menguntungkan kedua belah pihak di tengah keunggulan kompetitif yang dimiliknya, misalnya dalam aspek permodalan dan teknologi sehingga dapat mengurangi tingkat kompetisi dan kerugian akibat adanya potensi perpindahan nasabah. Selain itu, regulator perlu mendukung partnership model antara industri perbankan dan FinTech lending melalui penyusunan kebijakan yang tepat tanpa merugikan kedua industri.

\section{Daftar Pustaka}

[1] Al-hawari, M. A. (2014). Emotional stability and switching barriers in the retail banking context. Managing Service Quality: An International Journal, 24(5), 469-486. doi: https://doi.org/10.1108/MSQ-12-2013-0280.

[2] Bakar, J. A., Clemes, M. D., \& Bicknell, K. (2017). A comprehensive hierarchical model of retail banking. International Journal of Bank Marketing, 35(4), 662-684. doi: https:/ /doi.org/10.1108/IJBM-03-2016-0041.

[3] Bansal, H. S., Taylor, S. F., \& St. James, Y. (2005). "Migrating” to new service providers: Toward a unifying framework of consumers' switching behaviors. Journal of the Academy of Marketing Science, 33(1), 96-115. doi: 10.1177/0092070304267928.

[4] Edison, A. (2015). Modul Praktikum Metode Riset untuk Bisnis dan Manajemen. Universitas Widyatama.

[5] El-Habil, A. M. (2012). An application on multinomial logistic regression model. Pakistan Journal of Statistics and Operation Research, 8(2), 271-291. doi: https://doi.org/10.18187/pjsor.v8i2.234.

[6] Farah, M. F. (2017a). Application of the theory of planned behavior to customer switching intentions in the context of bank consolidations. International Journal of Bank Marketing, 35(1), 147-172. doi: https:/ /doi.org/10.1108/IJBM-01-2016-0003.

[7] Farah, M. F. (2017b). Consumers' switching motivations and intention in the case of bank mergers: a cross-cultural study. International Journal of Bank Marketing, 35(2), 254-274. doi: https://doi.org/10.1108/IJBM-05-2016-0067.

[8] Gerrard, P., \& Cunningham, J. B. (2004). Consumer switching behavior in the Asian banking market. Journal of Services Marketing, 18(3), 215-223. doi: https://doi.org/10.1108/08876040410536512.

[9] Hsu, J. L., \& Chang, W. H. (2007). Influences of brand and advertising cognition on brand-switching behaviour. International Journal of Management and Enterprise Development, 4(2), 159-178. doi: https:/ /doi.org/10.1504/IJMED.2007.011790.

[10] Jun, J., \& Yeo, E. (2018). Peer-to-peer lending platforms and the stability of the banking system. Proceeding of 31st Australasian Finance and Banking Conference 2018, 21 p. Diakses dari https:/ / papers.ssrn.com/sol3/papers.cfm?abstract_id=3221966.

[11] Kasali, R. (2017). Disruption. PT. Gramedia Pustaka Utama, Jakarta.

[12] Kasali, R. (2018). Self disruption: Bagaimana perusahaan keluar dari perangkap masa lalu dan mendisrupsi dirinya menjadi perusahaan yang sehat. Penerbit Mizan Anggota IKAPI, Jakarta.

[13] Koutsothanassi, E., Bouranta, N., \& Psomas, E. (2017). Examining the relationships among service features, customer loyalty and switching barriers in the Greek ban- 
king sector. International Journal of Quality and Service Sciences, 9(3/4), 425-440. doi: https://doi.org/10.1108/IJQSS-02-2017-0013.

[14] Lee, J., Ryu, M. H., \& Lee, D. (2019). A study on the reciprocal relationship between user perception and retailer perception on platform-based mobile payment service. Journal of Retailing and Consumer Services, 48, 7-15. doi: https://doi.org/10.1016/j.jretconser.2019.01.007.

[15] Li, C. Y. (2018). Consumer behavior in switching between membership cards and mobile applications: The case of Starbucks. Computers in Human Behavior, 84, 171-184. doi: https://doi.org/10.1016/j.chb.2017.12.042.

[16] Maier, E. (2016). Supply and demand on crowdlending platforms: connecting small and medium-sized enterprise borrowers and consumer investors. Journal of Retailing and Consumer Services, 33, 143-153. doi: http://dx.doi.org/10.1016/j.jretconser.2016.08.004.

[17] Malhotra, N. K. (2016). Marketing research: An applied orientation (6th Edition). Pearson India Education, Delhi.

[18] Piha, L. P., \& Avlonitis, G. J. (2015). Customer defection in retail banking: Attitudinal and behavioural consequences of failed service quality. Journal of Service Theory and Practice, 25(3), 304-326. doi: https:/ /doi.org/10.1108/JSTP-04-2014-0080.

[19] PricewaterhouseCoopers. (2016). Customers in the spotlight: How FinTech is reshaping banking (Global FinTech Survey 2016). PwC. Diakses dari https://www.pwc.com/gx/ en/industries/financial-services/publications/fintech-is-reshaping-banking.html.

[20] Schwab, K. (2017). The fourth industrial revolution. Currency.

[21] TransferWise. (2016, 8 Agustus). 2. Creating The Perfect Storm. Diakses dari https: transferwise.com/gb/blog/creating-the-perfect-storm.

[22] Vyas, V., \& Raitani, S. (2014). Drivers of customers' switching behaviour in Indian banking industry. International Journal of Bank Marketing. 32(4), 321-342. doi: https://doi.org/10.1108/IJBM-04-2013-0033.

[23] Wang, L., Luo, X. R., Yang, X., \& Qiao, Z. (2019). Easy come or easy go? Empirical evidence on switching behaviors in mobile payment applications. Information $\mathcal{E}$ Management, 56(7), 103150. doi: https:/ / doi.org/10.1016/j.im.2019.02.005.

[24] Ye, C., \& Potter, R. (2011). The role of habit in post-adoption switching of personal information technologies: An empirical investigation. Communications of the Association for Information Systems, 28(35), 585-610. doi: https:/ / doi.org/10.17705/1CAIS.02835. 